\title{
India's electioneers make bold pledges on science
}

\author{
Major parties back climate plan, but differ on nuclear policy.
}

Science features prominently in the manifestos of the main political parties contesting India's month-long general election, which began on 16 April.

The battle mainly involves two coalitions: the ruling left-of-centre United Progressive Alliance (UPA), led by the Indian National Congress (INC) party, and the National Democratic Alliance (NDA), led by the nationalist Bharatiya Janata Party (BJP). A third group made up of regional and Communist parties also has growing support. The five rounds of elections to select the 543 members of the Lok Sabha (the lower house of parliament) will last until 13 May, with the winners announced on 16 May and the new government taking power by 2 June. Pollsters predict that no party will win an absolute majority and expect another coalition government, with current prime minister Manmohan Singh in the frame to serve a second term.

Election promises made by the leading parties often fail to materialize, says physicist and former science minister M. G. K. Menon, although there have been significant exceptions in the past. "India's big leap in information technology today," he told Nature, "is the result of an election promise by the BJP in 1999, which was fulfilled during its rule."
During his five years in government, Singh has often emphasized the importance of science to the country's development. Singh's INC party has already committed to creating new Indian Institutes of Science Education and Research, and promises to continue its renewal of science and technology infrastructure "to attract and retain the best talent from India and abroad", according to its election manifesto.

But Thirumalachari Ramasami, who is secretary of the government's Department of Science and Technology, points out that although there is no shortage of political support for science in India, a key hurdle for further development is simply a lack of scientists. "We require people with ideas," he says, "but where are the people?"

Government spending on science research now stands at about $0.9 \%$ of gross domestic product, and is expected to rise to about $2 \%$ by 2012 , says Krishnaswami Kasturirangan, who headed the Indian Space Research Organisation in 1994-2003 and who is now a member of the upper house of parliament, the Rajya Sabha. Kasturirangan believes that the growth in India's science spending is likely to continue towards that target whichever party wins power.

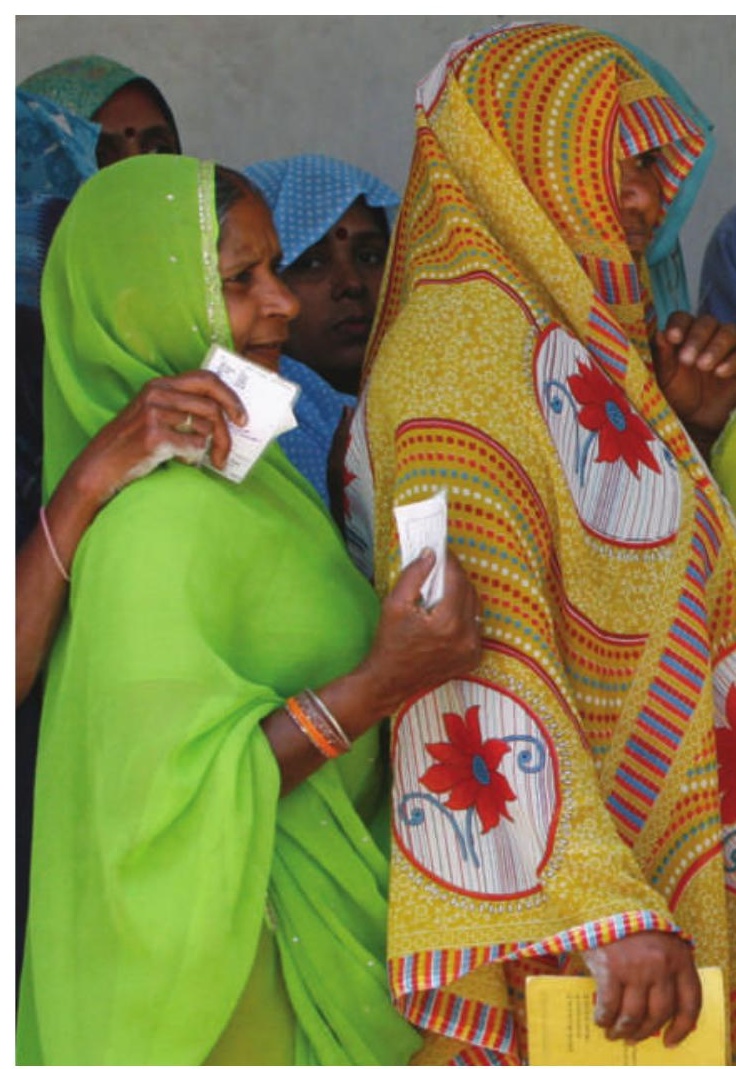

The BJP says that it aims to create funding mechanisms to promote basic research, although detailed plans have yet to be released. Citing biotechnology and materials science as priority areas, the party also promises to set up autonomous organizations to facilitate technology transfer from universities and national laboratories to industry, while giving academic institutions more freedom in spending

\section{SNAPSHOT Motion detector}

Satellite radar images are helping to pin down the origins of the magnitude 6.3 earthquake that devastated the Italian town of L'Aquila on 6 April.

Data taken before and after the quake by the Advanced Synthetic Aperture Radar instrument on the European Space Agency's Earthmonitoring satellite, Envisat, have been used to create an interferogram of the region (pictured). Each coloured fringe corresponds to 28 millimetres of ground motion, and shows that the ground east of the fault (shown) has risen while the basin containing L'Aquila has sunk. Geologists from the Institute for Electromagnetic Sensing of the Environment, part of the Italian National Research Council, and the National Institute of Geophysics and Volcanology in Rome produced the first interferograms of the site.

Richard Walters and John Elliott of the University of Oxford, UK, have now used the same data to model the earthquake, and concluded that the fault line ruptured for about 11 kilometres and slipped by about 80 centimetres.

Lucas Laursen

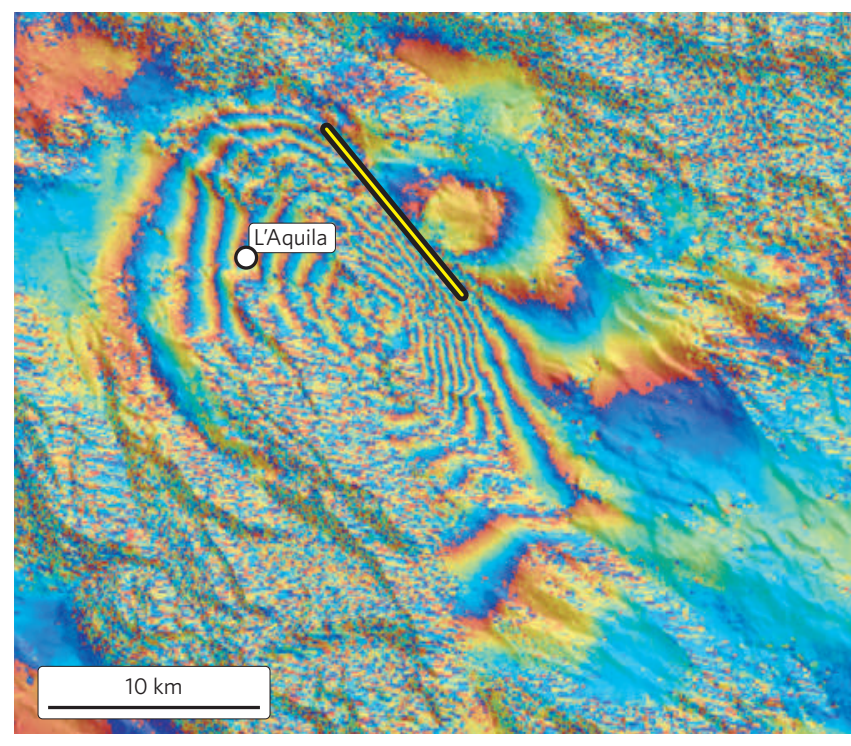




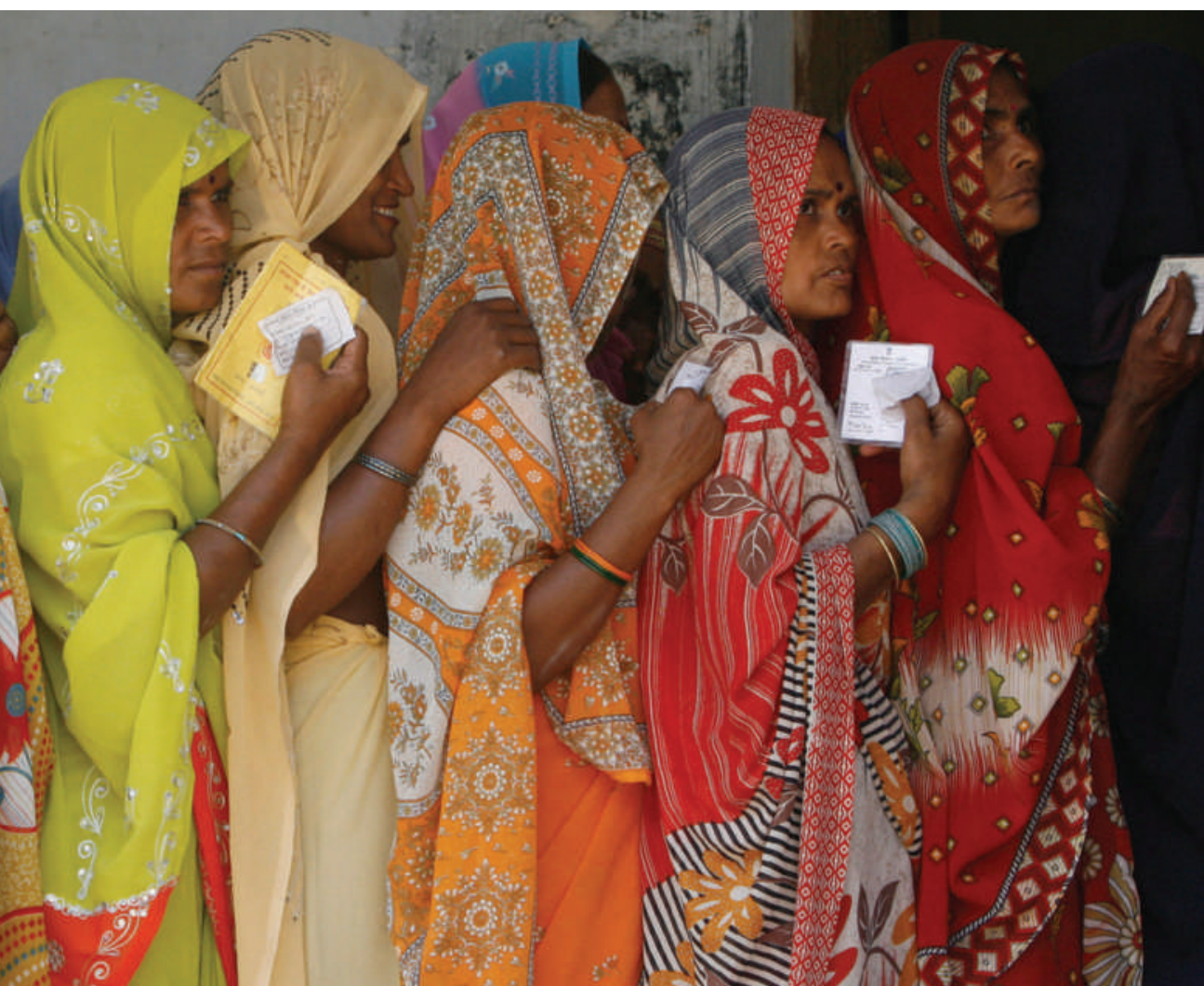

India's voters have begun the month-long process of electing their next government.

their budgets. The BJP also emphasizes the importance of international cooperation, saying that it will make science and technology "a key element" in foreign relations.

One important area where the parties disagree is the country's nuclear programme. Any shift in political power could have a marked impact on current plans for major growth in the nuclear energy industry, as the BJP intends to reverse the deal struck with the United States last year that would allow India to import reactors (see Nature 457, 134; 2009). The party says the deal will reduce the independence of India's domestic nuclear programme. Instead, the BJP would give "all financial assistance to expedite an indigenous thorium technology programme".

India owns about a quarter of the world's thorium deposits, around five times more than its modest uranium resources. Renewed investment in a thorium-based reactor programme would be a welcome development, says Padmanabha Krishnagopala Iyengar, former chairman of the Indian Atomic Energy Commission, who has criticized the Indo-US deal for making India too reliant on imported fuel and technology.

Although they diverge on many issues, the main coalitions back the National Action Plan on Climate Change that was unveiled by the Singh government in June 2008. This includes plans to boost solar-power capacity, shut down inefficient coal-fired power plants and raise the area of forest cover in the country from $23 \%$ to $33 \%$.

The BJP is also hoping to boost its environmental credentials with eye-catching proposals to clean the nation's widely polluted rivers, and enlist the help of India's citizens to plant a billion trees every year.

Both the BJP and the INC have pledged significant investment in information technology (IT), promising to bring broadband Internet access to every Indian village within three years. The BJP's manifesto includes plans to make computers more affordable for students and to link primary health centres to a satellite-based national telemedicine network that would allow patients in villages to have remote consultations with doctors in city hospitals. The BJP also says that it will set up a Digital Security Agency to deal with the rising threat of cyber warfare.

Although the suite of IT proposals is bold, computer scientist Narayanaswamy Balakrishnan, associate director of the Indian Institute of Science in Bangalore, believes they are feasible, "whichever party wants to do them".

\section{K. S. Jayaraman}

LIFE UNDER ICE

Unique chemistry allows microbes to thrive beneath Antarctic glacier.

www.nature.com/news

\section{French life-science alliance unveiled}

In a significant step towards the creation of a single life-sciences research council, the French government has forged an overarching alliance between the country's major agencies working in the field.

The National Alliance for Life and Health Sciences comprises eight bodies, including France's basic-research agency (CNRS), the national biomedical agency (INSERM) and the Pasteur Institute, based in Paris. Unveiled on 8 April, it will develop and coordinate national strategies in the life sciences and rationalize overlap between its members.

Although the structure of the agencies themselves will not change, the alliance will coordinate the planning for a research strategy on ten themes across all agencies.

In November 2008, an international panel of experts, including Elias Zerhouni and Harold Varmus, former directors of the US National Institutes of Health, and Leszek Borysiewicz, head of the UK Medical Research Council, reviewed French lifescience research and concluded that the field needs a drastic shake-up.

Their report criticized the complexity and fragmentation of life sciences in France, and the proliferation of duplicated programmes and regional clusters of research. It recommended that a single research council be set up for the field, charged with funding labs in universities and research agencies.

The alliance is a key step towards that goal, says Pierre Chambon, a member of the review panel and the founder and honorary director of the Institute of Genetics and Molecular and Cellular Biology near Strasbourg, France. He argues that a biology agency would give the field a stronger voice, and that the life sciences should be taken out of the CNRS, where it has long played second fiddle to the physical sciences.

Internal government working documents have also called for the alliance to be the embryo of a life-sciences agency.

But Alain Trautmann, a cell biologist at the Cochin Institute in Paris and former spokesman for the lobby group Let's Save Research, bemoans the alliance as evidence of a dismantling of the CNRS, calling it "the latest avatar created by our apparatchiks".

The alliance's steering group, composed of the heads of each member agency, will meet monthly to develop the strategy for their partnership.

Declan Butler 